\section{Preben Raunsbjerg}

\section{Tv-flader \& tv-fiktioner}

Henrik Søndergaard: DR i to-konkurrencens tidsalder, København 1994 (Samfundslitteratur).

Ib Bondebjerg: Elektroniske Fiktioner. $T v$ som fortallende medie, København 1993 (Borgen).

Danmarks Radios fjernsyn har i perioden fra starten af firserne til første halvdel af halvfemserne udviklet sig fra at vare 'programfjernsyn' til at blive et moderne 'programfladefjernsyn', og er nu ikke som tidligere en national kulturinstitution som formidler 'god kultur', men en programvirksomhed som producerer 'godt fjernsyn'.

Med det formål at eftervise disse teser udvælger Henrik Søndergaard i sin bog fra 1994 DR itv-konkurrencens tidsalder programfladen som sit primære analyseområde, og efter et kort første kapitel, hvor de indledende, afgrænsende manøvrer overstås, vender Henrik Søndergaard sig i bogens andet kapitel mod 'Programfladens æestetik'.

I Henrik Søndergaards fremstilling knytter begrebet 'æstetik' sig til organiseringen af det enkelte program i fladen, og de, der søger en diskussion eller en begrebsafklaring af æstetikbegrebet i almindelighed, og restetikbegrebet set i forhold til tv-mediet i særdeleshed, går her forgaves. Æstetikken som begreb har tidligere udvist stor modvilje mod at lade sig definere præcist, og det har nærmest udviklet sig til en art gummibegreb, som er blevet brugt til næsten hvad som helst. I Henrik Søndergaards anvendelse synes det pã et overordnet niveau at have txt forbindelse til 'form'siden af det dyadiske tegn-begreb, ligesom selve organiseringen af de enkelte programmer i programfladen for Henrik Søndergaard langt hen udgør 'æastetik ken'. Som begrebet anvendes i bogen, ville 'struktur' måske have været mindre problematisk, og under alle omstaendigheder ville en præcis begrebsafkla ring have været en stor fordel.

Ikke desto mindre giver bogen et godt overblik over teorier om programfladen. Udgangspunktet er Raymond Williams, nøgleordet er 'flow', og Henrik Søndergaard tilslutter sig synspunktet, at det særlige ved tv i højere grad skal findes i sammenbindingen af programmer, forløbet af programmer, end det skal findes i de enkelte programmers indhold.

Udover 'programflade' behandler bogen endnu et nøglebegreb, nemlig 'Public Service', som diskuteres både generelt og $\mathrm{i}$ forhold til institutionen DR. Al den diskussion man kunne savne $\mathrm{i}$ forhold til restetikbegrebet findes i rigt mål, når det gælder public service, og selv om Henrik Søndergaard efter eget udsagn ikke ønsker at beskæftige sig nævneværdigt med strukturelle ændringer i medielandskabet, lykkes det ham alligevel, bl.a. med udgangspunkt i en historisk behandling af public service begrebets betydningsmobilitet, at tydeligg $\varnothing$ re en række vasentlige og velplacerede pointer desangående.

Diskussionen af public service-begrebet lægger op til den efterfølgende programfladeanalyse, hvor én af mange interessante pointer er, at enkeltprogrammer som afspejler flowet, dvs. enkeltprogrammer som i sig selv mimer hele programfladens opbygning er genstand 
for en programpolitisk opprioritering i perioden efter monopolbruddet.

I fladeanalyserne udviser forfatteren stor forståelse for statistikkens faldgruber. Statistikkerne fortolkes, og der $g \phi-$ res i udstrakt grad opmærksom på de problemer der måtte være ved at drage konklusioner på baggrund af de foreliggende tal. Faktisk er Henrik Søndergaard nogle gange så forsigtig i forhold til sin egen udsigelseskraft, at en ikke statistisk kyndig person kunne få lyst til, helt uvidenskabeligt, at friste ham til at 'presse' tallene og de deraf følgende pointer lidt mere.

I bogens konklusionen skriver Henrik Søndergaard, at der ikke er nogen grund til at opsummere analysens resultater, eller gentage synspunkter som allerede er fremlagt. Hvor prisværdigt det end er ikke at ville gentage sig selv, er det $i$ dette tilfælde næsten ærgerligt, for med den store grundighed og sans for detaljen som analyserne bærer præg af, ville en opsummering af resultaterne gøre bogen noget mere letlæst. Dette ville ikke mindst være tilfældet, hvis de delkonklusioner som foretages undervejs markeredes mere tydeligt, i stedet for at stå som del af den $\emptyset$ vrige tekst. Man kunne have det synspunkt, at fremstillingen kan gøres mere flydende, năr man ikke forstyrres af opsummerende afsnit, og i en bog som beskriver tv's udvikling fra 'program' til 'flow' er der vel en slags retfærdighed $i$ at vælge en sådan fremstillingsform. Dog løber man også den risiko, at læseren overser nogle af pointerne, og en tydeliggørelse (og gerne opstramning) af bogens struktur ville sammen med en skarpere markering af synspunkter gøre den mere anvendelig, både for forskere og måske især for (universitets)studerende, sorn formodentlig udgør en ikke uvæsentlig del af bogens brugere.

Hvor Henrik Søndergaard behandler selve programfladen og flowet, går $\mathrm{Ib}$ Bondebjerg i Elektroniske fiktioner. Tv som fortallende medie fra 1993 ét trin dybere, idet han, mere traditionelt, analyserer en række enkeltstående tv-fiktioner. Opfattelsen af det serielle som noget centralt i forbindelse med tv skinner dog igennem Bondebjergs valg af analysemateriale, idet han netop vælger at analysere tv-føljetoner, nảr han skal undersøge tv som fortællende medie.

Bondebjerg lægger ud med et historisk afsnit, hvori han beskriver udviklingen fra paternalistisk tv til kommercielt tv. En sådan beskrivelse fïndes også $i$ Henrik Søndergaards bog, hvor hovedvægten lægges på den institutionelle udvikling. Hos Bondebjerg beskrives udviklingen med opmærksomheden rettet særligt mod periodens kulturdebat og gennemgangen giver et glimrende vue over de kulturelle skiermydsler, som har fundet sted i relation til tv. Som en ekstra bonus er denne gennemgang i særdeleshed, som resten af bogen er det $\mathrm{i}$ almindelighed, velskrevet og $i$ visse passager decideret underholdende.

At Bondebjerg vil foretage en analyse af enkeltprogrammer præger hans teorivalg. Selv om han starter med at tage afstand fra mange af de aktiviteter som fandt sted først og fremmest i halvfjerdserne under fællesnæuneren' 'kritisk teori', er en del af teoretikerne gengangere fra den tid. I den teoretiske gennemgang præsenteres vi således for både en psykologisk dimension og en semiotisk dimension (blandt andre), og de teoretiske kapitler 2 og 3 er pga. det indgående kendskab til og overblik over teorierne 
som udvises, sammen med første kapitel, grund nok til at købe bogen.

Men måske er det også den væesentligste grund, for nogle af analyserne har lidt svært ved at leve op til resten. Bondebjerg valger at analysere $6 \mathrm{tv}$-fiktioner, med Matador og Twin Peaks som to yderpunkter. Bortset fra analyserne af Heimat og The Singing Detective, som begge er glimrende, sker der med al mulig respekt ikke det helt store for restens vedkommende. Alt er grundigt og gennemarbejdet, men de fleste analyser fremstår for beskrivende, for indlysende, ja, næsten for acceptable og plausible: Man savner den vanvittige og urimelige overfortolkning, som făr én til at spilde kaffe i bogen, og i højere grad giver én lyst til at diskutere analysens udfald. Det virker næsten som om ivrigheden efter at lægge afstand til den kritiske teori og den (nogle gange noget overgearede) analytiske tradition, der fulgte i kølvandet på den, har fået Bondebjerg til at drosle helt ned i sine analyser.

En anden og måske mere sandsynlig årsag til den tilsyneladende iver efter at producere 'fornuftige analyser' er Bondebjergs erklærede interesse for det, som kommer såvel før som efter selve teksten, nemlig den foregående/efterfølgende behandling af teksten i det sociale rum som ligger uden for teksten: det, der siges og skrives om teksten i tv, ugeblade, aviser etc. Man kan forestille sig, at behandlingen af dette aspekt kunne tænkes at handicappe selve tekstlæsningen, da en 'overfortolkning' ville svække forbindelsen til de omgivende tekster (prøv fx at sætte Ove Christensen og Claus K. Kristiansens analyse af »Twin Peaks« $(K \& K$ nr. 71$)$ i direkte forbindelse med den omgivende verden).

Ikke mindst som undervisningsmateriale på universiteterne og beslægtede steder er Elektroniske Fiktioner aldeles glimrende. Bondebjergs meget anvendelige stikordsregister tilfører den, udover de allerede nævnte lærebogskvaliteter, kvaliteter som opslagsværk, noget man ellers ikke med rimelighed kan forlange af et vark som dette. Det er desuden rart, at forfatteren så̀ tydeligt som det er tilfældet her, markerer sin egen position i forhold til både teorier og analysemateriale. Bogen har, manglerne til trods, kvaliteter til at blive et standardværk i arbejde med tv og tv-fiktioner. 